\title{
ANALISIS PENERAPAN PSAP NO. 07 TAHUN 2010 TENTANG AKUNTANSI ASET TETAP PADA BADAN PENGELOLAAN KEUANGAN ASET PENDAPATAN DAERAH (BPKAPD) KABUPATEN MUNA BARAT
}

\author{
Oleh \\ La Ode Anto ${ }^{1}$, Tuti Dharmawati ${ }^{2}$, Sarfia $^{3}$ \\ Jurusan Akuntansi Fakultas Ekonomi dan Bisnis Universitas Halu Oleo Kendari \\ Sulawesi Tenggara
}

\begin{abstract}
ABSTRAK
Penelitian ini bertujuan untuk mengetahui dan menganalisis Penerapan PSAP No 07 Tahun 2010 tentang akuntansi aset tetap pada Badan Pengelolaan Keuangan Aset Dan Pendapatan (BPKAPD) Kabupaten Muna Barat. Jenis data yang digunakan yaitu data kualitatif dan data kuantitatif. Sumber data yang digunakan adalah data primer dan data sekunder. Pengumpulan data dilakukan dengan cara dokumentasi dan wawancara. Metode analisis data yang digunakan adalah metode analisis deskriptif.Hasil penelitian ini menunjukkan bahwa Perlakuan akuntansi aset tetap Pada Badan Pengelolaan Keuangan Aset Dan Pendapatan Daerah (BPKAPD) Kabupaten Muna Barat meliputi klasifikasi, pengakuan, pengukuran, penilaian awal aset tetap, pengukuran berikutnya terhadap pengakuan awal yaitu Penyusutan dan penilaian kembali aset tetap, pengungkapan dan penghentian dan pelepasan aset tetap sesuai dengan PSAP No.07 tahun 2010, kecuali Penyusutan Aset Tetap belum sepenuhnya sesuai. Penyusutan aset tetap belum sepenuhnya sesuai dengan PSAP No.07 tahun 2010 karena tidak melakukan penyusutan terhadap aset tetap lainnya. Berdasarkan wawancara dengan bapak Lifan,staf bidang Aset BPKAPD Muna Barat, aset tetap lainnya tidak disusutkan, belum ada kebijakan Bupati mengenai penyusutan Aset tetap lainnya dan juga sejak pertama dibuat laporan keuangan pemerintah Kabupaten Muna Barat tahun 2015 memang tidak pernah melakukan penyusutan pada aset tetap lainnya.
\end{abstract}

KataKunci:Akuntansi Aset tetap, PSAP Nomor 07

\section{ABSTRACT}

This study aims to determine and analyze the application of PSAP No. 07/2010 concerning fixed asset accounting at the Asset and Income Financial Management Agency (BPKAPD) West Muna Regency. The type of data used is qualitative data and quantitative data. The data sources used are primary data and secondary data. Data collection was done by means of documentation and interviews. The data analysis method used is descriptive analysis method. The results of this study indicate that the accounting treatment of fixed assets at the West Muna Regency Financial Management Agency (BPKAPD) includes classification, recognition, measurement, initial assessment of fixed assets, subsequent measurements of initial recognition, namely depreciation and revaluation of fixed assets, disclosure and discontinuation and disposal of property and equipment in accordance with PSAP No. 07 of 2010, except for Depreciation of Fixed Assets not yet fully compliant. Depreciation of property and equipment is not fully in accordance with PSAP No. 07 of 2010 because it does not depreciate other fixed assets. Based on an interview with Mr. Lifan,the asset officer of the west Muna BPKAPD, other fixed assets are not depreciated, there has been no policy of the Regent regarding the depreciation of other fixed assets and also since the first financial statements of the West Muna Regency government in 2015 have never depreciated other fixed assets .

Keywords: Fixed Asset Accounting, PSAP Number 07 


\section{PENDAHULUAN}

Laporan keuangan sektor pemerintahan disusun sesuai dengan status instansi tersebut, apakah baik entitas pelaporan atau entitas akuntansi. Menurut SAP PP No.24 Tahun 2005[1], entitas pelaporan harus menyusun empat jenis laporan keuangan pokok yaitu Laporan Realisasi Anggaran (LRA), Neraca, Laporan Arus Kas (LAK), dan Catatan atas Laporan Keuangan (CaLK) serta diperkenankan menyusun kinerja keuangan dan Laporan Perubahan Ekuitas (LPE), sedangkan entitas akuntansi hanya menyusun Laporan Realisasi Anggaran, Neraca, Catatan atas Laporan Keuangan. Sementara itu, menurut SAP PP No.71 Tahun 2010[2] entitas pelaporan harus menyusun tujuh laporan keuangan yaitu Laporan Realisasi Anggaran,Laporan Saldo Anggaran Lebih (Laporan Perubahan SAL), Neraca, Laporan Operasional (LO), Laporan Arus Kas, Laporan Perubahan Ekuitas, dan Catatan atas Laporan Keuangan, sedangkan entitas akuntansi hanya diharuskan menyusun lima jenis laporan keuangan yaitu Laporan Realisasi Anggaran, Neraca,Laporan Operasional (LO), Laporan Perubahan Ekuitas, dan Catatan atas Laporan Keuangan.

Dari berbagai jenis laporan keuangan yang harus disusun, Neraca merupakan salah satu komponen penting laporan keuangan karena menggambarkan posisi keuangan suatu entitas terkait aset, kewajiban, dan ekuitas pada tanggal tertentu. Salah satu pos/akun penting dalam Neraca adalah Aset/Aktiva, karena aktiva dapat memberikan manfaat ekonomis bagi organisasi di masa depan.

Salah satu aspek penting dalam pengelolaan aset tetap yaitu penyusutan yang meliputi perhitungan dan pelaporan penyusutan. Menurut Mursyidi (dalam Rumbaru dkk, 2018:211)[4] penyusutan memungkinkan pemerintah mendapatkan informasi tentang aset tetap yang dimilikinya. Nilai aset tetap harus disusutkan setiap periodenya oleh pengguna aset, sehingga dapat menggambarkan potensi sebenarnya dari aset tetap tersebut.

Hasil wawancara peneliti pada Badan Pengelolaan Keuangan Aset Dan Pendapatan Daerah (BPKAPD) Kabupaten Muna Barat Provinsi Sulawesi Tenggara bagian staf bidang aset terkait dengan standar akuntansi bahwa sudah menerapkan Peraturan Pemerintah No. 71 Tahun 2010 dan juga menerapkan Peraturan Bupati No. 59 Tahun 2017 tentang kebijakan akuntansi pemerintah kabupaten Muna Barat. Kebijakan akuntansi tersebut mengacu pada Peraturan Pemerintah No. 71 Tahun 2010, dengan menggunakan akuntansi berbasis akrual yang disesuaikan dengan keadaan atau kondisi di pemerintahan Kabupaten Muna Barat dalam perlakuan akuntansinya. Tetapi setelah melihat data awal yaitu Laporan Rekapitulasi Penyusutan Tahun 2018 tidak melakukan penyusutan terhadap Aset Tetap Lainnya. Adapun Laporan Rekapitulasi Penyusutan Aset tetap Tahun 2018 pemerintah Kabupaten Muna Barat Yaitu:

Tabel 1.1

Laporan Rekapitulasi PenyusutanAset Tetap Tahun 2018 Pemerintah Kabupaten Muna Barat

\begin{tabular}{|c|c|c|c|c|c|c|c|}
\hline \multicolumn{8}{|c|}{$\begin{array}{c}\text { PEMERINTAH KABUPATEN MUNA BARAT } \\
\text { LAPORAN REKAPITULASI PENYUSUTAN } \\
\text { Sampai dengan } 31 \text { Desember } 2018 \\
\end{array}$} \\
\hline \multirow[b]{2}{*}{ No } & \multirow[b]{2}{*}{ Nama Aset } & \multirow[b]{2}{*}{ Nilai Perolehan } & \multirow{2}{*}{$\begin{array}{c}\text { Akumulasi } \\
\text { Penyusutan } \\
1 \text { Jan } 2018\end{array}$} & \multicolumn{2}{|c|}{ Penyusutan } & \multirow{2}{*}{$\begin{array}{c}\text { Akumulasi } \\
\text { Penyusutan } \\
\text { 31 Des } 2018\end{array}$} & \multirow{2}{*}{$\begin{array}{l}\text { Nilai Buku } \\
31 \text { Des. } 2018\end{array}$} \\
\hline & & & & Semester 1 & Semester 2 & & \\
\hline 1 & Tanah & $2,394,250,000$ & 0 & 0 & 0 & 0 & $2,394,250,000$ \\
\hline 2 & $\begin{array}{l}\text { Peralatan } \\
\text { Mesin }\end{array}$ & $86,248,484,440$ & $10,952,977,118$ & $5,030,365,767$ & $7,245,687,589$ & $23,229,030,474$ & $63,019,453,966$ \\
\hline 3 & $\begin{array}{l}\text { Gedung } \\
\text { Bangunan }\end{array}$ & $129,224,286,296$ & $747,609,824$ & $715,894,518$ & $1,678,311,356$ & $3,141,815,698$ & $126,082,470,598$ \\
\hline
\end{tabular}


Jurnal Akuntansi dan Keuangan (JAK)

Volume 6, No. 1 Februari Tahun 2021

Page: $124-136$

http://ojs.uho.ac.id/index.php/jak-uho/issue/archive

e-ISSN: 2088-4656

\begin{tabular}{|l|l|r|r|r|r|r|r|}
\hline $\mathbf{4}$ & $\begin{array}{l}\text { Jalan } \\
\text { Irigasi } \\
\text { Jaringan }\end{array}$ & $636,784,777,716$ & $49,762,993,716$ & $20,450,589,562$ & $23,250,963,795$ & $93,464,547,073$ & $543,320,230,643$ \\
\hline $\mathbf{5}$ & $\begin{array}{l}\text { Aset tetap } \\
\text { lainnya }\end{array}$ & $9,003,226,000$ & 0 & 0 & 0 & 0 & $9,003,226,000$ \\
\hline $\mathbf{6}$ & $\begin{array}{l}\text { Konstruksi } \\
\text { dalam } \\
\text { pengerjaan }\end{array}$ & $27,447,519,772$ & 0 & 0 & 0 & 0 & $27,447,519,772$ \\
\hline Jumlah & $\mathbf{8 9 1 , 1 0 2 , 5 4 4 , 2 2 4}$ & $\mathbf{6 1 , 4 6 3 , 5 8 0 , 6 5 8}$ & $\mathbf{2 6 , 1 9 6 , 8 4 9 , 8 4 7}$ & $\mathbf{3 2 , 1 7 4 , 9 6 2 , 7 4 0}$ & $\mathbf{1 1 9 , 8 3 5 , 3 9 3 , 2 4 5}$ & $\mathbf{7 7 1 , 2 6 7 , 1 5 0 , 9 7 9}$ \\
\hline
\end{tabular}

Sumber : Badan Pengelolaan Keuangan Aset Dan Pendapatan Daerah (BPKAPD)

Kabupaten Muna Barat (dalam satuan rupiah)

SAP PP No 71 Tahun 2010,dalam PSAP No.07[3] dalam hal penyusutan, selain tanah dan konstruksi dalam pengerjaan,seluruh aset tetap dapat disusutkan sesuai dengan sifat dan karakteristik aset tesebut. Namun berdasarkan data di atas yang di peroleh dari Badan Pengelolaan Keuangan Aset Dan Pendapatan Daerah (BPKAPD) Kabupaten Muna Barat, selain tanah dan konstruksi dalam pengerjaan tidak disusutkan, aset tetap lainnya juga tidak dilakukan penyusutan. Aset tetap lainnya tidak disusutkan karena pemerintah Kabupaten Muna Barat masih mengacu pada peraturan Bupati Muna Barat Nomor 59 tahun 2017, dimana belum menerapkan peraturan mengenai penyusutan aset tetap lainnya (Lifan,pegawai staf bidang Aset BPKAPD Muna Barat).

Penelitian ini dilakukan untuk mengetahui dan menganalisis Penerapan PSAP NO. 07 Tahun 2010 Tentang Akuntansi Aset Tetap Pada Badan Pengelolaan Keuangan Aset Dan Pendapatan Daerah (BPKAPD) Kabupaten Muna Barat”.

\section{TINJAUAN PUSTAKA \\ Pernyataan Standar Akuntansi Pemerintah (PSAP)}

Pernyataan Standar akuntansi pemerintahan (PSAP) adalah prinsip-prinsip akuntansi yang diterapkan dalam menyusun dan menyajikan Laporan Keuangan Pemerintah (LKP).Laporan tersebut seperti misalnya Laporan Keuangan Pemerintah Pusat (LKPP) dan Laporan Keuangan Pemerintah Daerah (LKPD).Dalam membantu penerapannya, Penerapan Standar Akuntansi Pemerintah (PSAP) ini dibarengi dengan Interpretasi Pernyataan Standar Akuntansi Pemerintahan (IPSAP) atau Buletin Teknis Standar Akuntansi Pemerintah (SAP).Gunanya adalah untuk menghindari salah arti dari penggunaan Pernyataan Standar Akuntansi Pemerintah (PSAP) dan mengatasi permasalahan teknis.Interpretasi Pernyataan Standar Akuntansi Pemerintahan (IPSAP) dan Buletin Teknis Standar Akuntansi Pemerintah (SAP) disusun dan diterbitkan oleh Komite Standar Akuntansi Pemerintahan (KSAP) dan diberitahukan kepada Pemerintah Badan Pemeriksa Keuangan (BPK).Tujuan Pernyataan Standar Akuntansi Pemerintahan (PSAP) adalah untuk mengatur perlakuan akuntansi untuk aset tetap meliputi pengakuan, penentuan nilai tercatat, serta penentuan dan perlakuan akuntansi atas penilaian kembali dan penurunan nilai tercatat aset tetap.

\section{Pengertian Aset Tetap}

Aset tetap dalam PSAP No. 07 di definisikan sebagai aset berwujud yang mempunyai masa manfaat lebih dari 12 (dua belas) bulan untuk digunakan, atau dimaksudkan untuk digunakan, dalam kegiatan pemerintah atau dimanfaatkan oleh masyarakat umum.

\section{Klasifikasi Aset Tetap}

Aset tetap dalam PSAP No. 07 diklasifikasikan berdasarkan kesamaan sifat atau fungsinya dalam aktivitas operasi entitas. Klasifikasi aset tetap adalah sebagai berikut: (1)Tanah;(2)Gedung dan Bangunan;(3)Peralatan dan Mesin;(4)Jalan, Irigasi, dan Jaringan;(5)Aset Tetap Lainnya;(6)Konstruksi dalam Pengerjaan 


\section{Pengakuan Aset Tetap}

PSAP No. 07 Paragraf 15 menyatakan bahwa aset tetap diakui pada saat manfaat ekonomi masa depan dapat diperoleh dan nilainya dapat diukur dengan handal. Aset tetap untuk dapat diakui sebagai aset tetap harus memenuhi kriteria sebagai berikut, yaitu: berwujud, mempunyai masa manfaat lebih dari 12 (dua belas) bulan, biaya perolehan aset dapat diukur secara andal, tidak dimaksudkan untuk dijual dalam operasi normal entitas, dan diperoleh atau dibangun dengan maksud untuk digunakan.

\section{Pengukuran Aset Tetap}

Berdasarkan PSAP No. 07 Paragraf 20, Aset tetap dinilai dengan biaya perolehan. "Apabila penilaian aset tetap dengan menggunakan biaya perolehan tidak memungkinkan maka nilai aset tetap didasarkan pada nilai wajar pada saat perolehan.Kemudian dikatakan bahwa "apabila penilaian aset tetap dengan menggunakan biaya perolehan tidak memungkinkan maka nilai aset tetap didasarkan pada nilai wajar pada saat perolehan". (Komite Standar Akuntansi Pemerintahan 2016: par.20) [14]

\section{Penilaian Awal Aset tetap}

Mengenai penilaian awal aset tetap, dalam Pernyataan Standar Akuntansi Pemerintahan No. 07 disebutkan, "Barang berwujud yang memenuhi kualifikasi untuk diakui sebagai suatu aset dan dikelompokkan sebagai aset tetap, pada awalnya harus diukur berdasarkan biaya perolehan" (Komite Standar Akuntansi Pemerintahan 2016: par. 23). Selanjutnya dikatakan bahwa "Apabila aset tetap diperoleh tanpa nilai, biaya aset tersebut adalah sebesar nilai wajar pada saat aset tersebut diperoleh" (Komite Standar Akuntansi Pemerintahan 2016 : par. 24).[14]

\section{Pengeluaran setelah Perolehan (subsequent Expenditure)}

Setiap pengeluaran memerlukan analisis lebih lanjut untuk menentukan apakah pengeluaran tersebut akan dikapitalisasi atau dibebankan pada tahun berjalan. Hal ini dijelaslan dalam Peraturan Pemerintah No.71 Tahun 2010, dalam PSAP No. 07 paragraf 49-51[3] disebutkan bahwa : "Pengeluaran setelah perolehan awal suatu aset tetap yang memperpanjang masa manfaat atau yang kemungkinan besar memberi manfaat ekonomis di masa yang akan datang dalam bentuk kapasitas, mutu produksi, atau peningkatan standar kinerja, harus ditambahkan pada nilai tercatat aset yang bersangkutan". Kemudian ditetapkan bahwa setiap entitas harus menentukan batasan jumlah biaya tertentu (capitalization thresholds) tertentu yang digunakan untuk memisahkan pengeluaran yang dapat dikapitalisasi dan yang tidak dapat dikapitalisasi.

\section{Pengukuran Berikutnya Terhadap Pengakuan Awal Penyusutan Aset Tetap}

Menurut Buletin Teknis Nomor 18 SAP (2014:1)[16] Penyusutan adalah alokasi yang sistematis atas nilai suatu aset tetap yang dapat disusutkan (depreciable assets) selama masa manfaat aset yang bersangkutan.Selain tanah dan konstruksi dalam pengerjaan, seluruh aset tetap dapat disusutkan sesuai dengan sifat dan karakteristik aset tersebut (PSAP No. 7 Paragraf 58 PP No. 71 Tahun 2010)[3]. Berikut ini beberapa metode yang dapat digunakan dalam penyusutan aset tetap, diantaranya: (a) Metode Garis Lurus (Straight Line), (b) Metode Saldo Menurun Berganda (double declining belence method) dan (c) Metode Unit Produksi (unit productive method).

\section{Penilaian Kembali Aset Tetap (Revaluation)}

Berdasarkan PSAP 07 menyatakan bahwa "Penilaian kembali atau revaluasi aset tetap pada umumnya tidak diperkenankan karena Standar Akuntansi Pemerintahan menganut penilaian aset berdasarkan biaya perolehan atau harga pertukaran. Penyimpangan 
dari ketentuan ini mungkin dilakukan berdasarkan ketentuan pemerintah yang berlaku secara nasional'(Komite Standar Akuntansi Pemerintahan 2016 : par. 59).[14]

\section{Pengungkapan Aset Tetap}

Mengenai pengungkapan aset tetap, Komite Standar Akuntansi Pemerintahan (2016 : par. 80)[14] menyatakan dalam Pernyataan Standar Akuntansi Pemerintahan menyatakan bahwa laporan keuangan harus mengungkapkan untuk masing-masing jenis aset tetap sebagai berikut:

a. Dasar penilaian yang digunakan untuk menentukan nilai tercatat (carrying amount).

b. Rekonsiliasi jumlah tercatat pada awal dan akhir periode yang menunjukkan: (1) Penambahan, (2) Pelepasan, (3) Akumulasi penyusutan dan perubahan nilai, jika ada dan (3) Mutasi aset tetap lainnya

c. Informasi penyusutan, meliputi: (1) Nilai penyusutan, (2) Metode penyusutan yang digunakan, (3) Masa manfaat atau tarif penyusutan yang digunakan, (d) Nilai tercatat bruto dan akumulasi penyusutan pada awal dan akhir periode.

\section{Penghentian dan Pelepasan Aset Tetap}

Dalam Pernyataan Standar Akuntansi Pemerintahan bahwa,"Suatu aset tetap dieliminasi dari neraca ketika dilepaskan atau bila aset secara permanen dihentikan penggunaannya dan tidak ada manfaat ekonomis masa yang akan datang" (Komite Standar Akuntansi Pemerintahan 2016 : par. 77)[14]. Suatu aset tetap mungkin akan dihentikan penggunaannya karena tidak lagi mempunyai manfaat ekonomis di masa mendatang. Selanjutnya, dalam Pernyataan Standar Akuntansi Pemerintahan No. 07 disebutkan, "Aset tetap yang secara permanen dihentikan atau dilepas harus dieliminasi dari Neraca dan diungkapkan dalam Catatan atas Laporan Keuangan"(Komite Standar Akuntansi Pemerintahan 2016 : par. 78)[14].

\section{METODE PENELITIAN}

Lokasi merupakan suatu tempat atau wilayah penelitian tersebut akan dilakukan. Adapun penelitian ini di lakukan di Badan Pengelolaan Keuangan Aset dan Pendapatan Daerah Muna Barat.Objek dalam penelitan ini adalah penerapan PSAP No. 07 Tahun 2010 tentang akuntansi aset tetap pada Badan Pengelolaan Keuangan Aset dan Pendapatan Daerah Muna Barat.

Jenis data yang di gunakan dalam penelitian ini adalah data kualitatif dan data kuantitatif. Data kualitatif dalam penelitian ini berupa hasil wawancara mengenai penerapan PSAP 07 tentang akuntansi aset tetap, kebijakan akuntansi dan literatur-literatur yang mendukung dan data kuantitatif dalam penelitian ini seperti laporan keuangan pada Badan Pengelolaan Keuangan Aset dan Pendapatan Daerah Muna Barat periode 2018 yang meliputi Neraca dan Catatan atas Laporan Keuangan.

Sumber data yang digunakan dalam penelitian ini adalah data primer dan data sekunder.Data primer adalah data yang diperoleh langsung dari wawancara dengan Kepala Badan Pengelolaan Keuangan Aset dan Pendapatan Daerah Muna Barat, Kepala Bidang bagian aset tetap pada Badan Pengelolaan Keuangan Aset dan Pendapatan Daerah Muna Barat dan Staf bagian aset tetap pada Badan Pengelolaan Keuangan Aset dan Pendapatan Daerah Muna Barat dan data sekunder adalah data yang diperoleh melalui dokumendokumen, literatur dan informasi yang berkaitan dengan penelitian ini.

Metode pengumpulan data yang digunakan dalam penelitian ini adalah Metode Wawancara dan Dokumentasi.Wawancara dalam penelitian ini adalah Kepala Badan Pengelolaan Keuangan Aset dan Pendapatan Daerah (BPKAPD) Muna Barat, Kepala Bidang bagian aset tetap BPKAPD Muna Barat dan Staf bagian aset tetap BPKAPD Muna Barat dan dokumentasi adalah dilakukan dengan mengumpulkan data dari laporan-laporan dan dokumen-dokumen terkait perlakuan akuntansi aset tetap berupa gambaran umum 
aktivitas akuntansi, laporan keuangan tahunan, dan kebijakan akuntansi yang diterapkan Badan Pengelolaan Keuangan Aset dan Pendapatan Daerah Muna Barat.

Metode yang digunakan untuk menganalisis data penelitian ini adalah analisis deskriptif yaitu mendiskripsikan penerapan akuntansi aset tetap menurut Badan Pengelola Keuangan Aset Dan Pendapatan Kabupaten Daerah Muna Barat yang disesuaikan dengan PSAP Nomor 07 tentang akuntansi aset tetap.

\section{HASIL DAN PEMBAHASAN}

\section{Hasil Penelitian}

\section{Definisi Aset Tetap Menurut BPKAPD Kabupaten Muna Barat}

Badan Pengelolaan Keuangan Aset dan Pendapatan Daerah Kabupaten Muna Barat mendefinisikan aset tetap berdasarkan Peraturan Bupati nomor 59 tahun 2017[29] tentang kebijakan akuntansi Muna Barat bahwa aset tetap adalah aset berwujud yang mempunyai masa manfaat lebih dari 12 (duabelas) bulan untuk digunakan atau dimaksudkan untuk digunakan, dalam kegiatan pemerintah daerah atau dimanfaatkan oleh masyarakat umum. Termasuk dalam aset tetap pemerintah adalah: (a) Aset tetap yang dimiliki oleh entitas pelaporan namun dimanfaatkan oleh entitas lainnya, misalnya instansi pemerintah lainnya, universitas, dan kontraktor; (b) Hak atas tanah.

\section{Klasifikasi Aset Tetap BPKAPD Muna Barat}

Dalam pengklasifikasian aset tetap oleh Badan Pengelolaan Keuangan Aset dan Pendapatan Daerah Kabupaten Muna Barat mengklasifikasikan aset tetap ke dalam 6 (enam) golongan yang mengacu pada Peraturan Bupati nomor 59 tahun 2017[29], aset tetap terdiri atas: (a) Tanah, (b)Gedung dan bangunan, (c) Mesin dan peralatan, (d)Jalan irigasi dan bangunan, (e) Aset tetap lainnya, dan (f) Konstruksi dalam pengerjaan.

\section{Pengakuan Aset tetap pada BPKAPD Muna Barat}

Bapak Lifan selaku staf bidang Aset pada BPKAP Muna Barat, juga mengatakan bahwa aset tetap diakui apabila perolehannya sah baik itu dari belanja modal ataupun hibah,dan aset tetap diakui apabila memenuhi kriteria seperti mempunyai masa manfaat lebih dari 12 (dua belas) bulan, biaya perolehan aset dapat diukur secara andal, tidak dimaksudkan untuk dijual dalam operasi normal entitas, diperoleh atau dibangun dengan maksud untuk digunakan dan memenuhi batas minimum kapitalisasi aset tetap yang telah ditentukan oleh pemerintah daerah. Lebih lanjut bapak lifan mengatakan untuk aset tetap yang tidak ditetapkan batas minimum kapitalisasinya,berapapun nilai perolehannya seluruhnya dikapitalisasi sebagai nilainya.

\section{Pengukuran Aset Tetap BPKAPD Muna Barat}

Badan Pengelolaan Keuangan Aset dan Pendapatan Daerah Kabupaten Muna Barat untuk Pengukuran aset tetap berdasarkan Peraturan Bupati nomor 59 tahun 2017[29],dalam pengukuran aset tetap dinilai dengan biaya perolehan. Apabila penilaian aset tetap dengan menggunakan biaya perolehan tidak memungkinkan maka nilai aset tetap didasarkan pada nilai wajar pada saat perolehan. Biaya perolehan aset tetap yang dibangun dengan cara swakelola meliputi biaya langsung untuk tenaga kerja, bahan baku, dan biaya tidak langsung termasuk biaya perencanaan dan pengawasan, perlengkapan, tenaga listrik, sewa peralatan, dan semua biaya lainnya yang terjadi berkenaan dengan pembangunan aset tetap tersebut. Bila aset tetap diperoleh dengan tanpa nilai, biaya aset tersebut adalah sebesar nilai wajar pada saat aset tersebut diperoleh.

\section{Penilaian Awal Aset Tetap BPKAPD Muna Barat}


Badan Pengelolaan Keuangan Aset dan Pendapatan Daerah Kabupaten Muna Barat,dalam melakukan penilaian awal aset tetap berdasarkan peraturan Bupati nomor 59 tahun 2017[29]bahwa dalam penilaian awal aset tetap, barang berwujud yang memenuhi kualifikasi untuk diakui sebagai suatu aset dan dikelompokkan sebagai aset tetap, pada awalnya harus diukur berdasarkan biaya perolehan.Bila aset tetap diperoleh dengan tanpa nilai, biaya aset tersebut adalah sebesar nilai wajar pada saat aset tersebut diperoleh.

\section{Pengeluaran Setelah Perolehan BPKAPD Muna Barat}

Berdasarkan wawancara dengan bapak Lifan staf bidang Aset BPKAPD Muna Barat mengatakan bahwa pengeluaran-pengeluaran setelah perolehan aset tetap memiliki kriteria kapitalisasi aset tetap yang telah diatur dalam kebijakan Bupati Nomor 59 Tahun 2017. Pengeluaran yang memenuhi kriteria kapitalisasi aset tetap maka diakui sebagai belanja modal dan pengeluaran tersebut dikapitalisasi menjadi aset.Apabila pengeluaran tersebut tidak memenuhi kriteria kapitalisasi aset misalnya kurang dari batasan biaya minimum kapitalisasi aset tetap maka diakui sebagai belanja barang dan jasa.

\section{Pengukuran Berikutnya Terhadap Pengakuan Awal BPKAPD Muna Barat Penyusutan Aset Tetap}

Badan Pengelolaan Keuangan Aset dan Pendapatan Daerah Kabupaten Muna Barat, dalam melakukan penyusutan aset tetap berdasarkan peraturan Bupati Nomor 59 Tahun 2017[29] bahwa Penyusutan adalah alokasi yang sistematis atas nilai suatu Aset tetap yang dapat disusutkan (depreciable assets) selama masa manfaat Aset yang bersangkutan. Adapun Metode penyusutan digunakan seperti yang tercantum dalam peraturan Bupati Nomor 59 Tahun 2017 adalah menggunakan metode garis lurus (straight line method), tanpa nilai sisa.

\section{Penilaian Kembali Aset Tetap}

Badan Pengelolaan Keuangan Aset dan Pendapatan Daerah Kabupaten Muna Barat, dalam hal penilaian kembali aset tetap berdasarkan Peraturan Bupati Nomor 59 tahun 2017[29] bahwa Penilaian kembali atau revaluasi aset tetap tidak diperkenankan di pemerintah Kabupaten Muna Barat karena kebijakan akuntansi pemerintah daerah menganut penilaian aset berdasarkan biaya perolehan atau harga pertukaran. Hal ini dijelaskan juga Bapak Lifan, selaku staf bidang Aset BPKAPD Muna Barat mengatakan bahwa Pemerintah Muna Barat tidak melakukan penilaian kembali terhadap aset tetap karena nilai aset tetap berdasarkan harga perolehan.

\section{Pengungkapan aset tetap BPKAPD Muna Barat}

Berdasarkan pengamatan peneliti pada CaLK Kabupaten Muna Barat tahun 2018 bahwa pengungkapan aset tetap yang diungkapkan antara lain nilai tercatat aset tetap, rekonsiliasi jumlah tercatat pada awal sampai akhir periode yang menunjukkan penambahan dan pengurangan aset tetap, kebijakan akuntansi aset tetap mengenai pengakuan sampai pengentian dan pelepasan aset tetap, dan informasi penyusutan yang menunjukkan nilai penyusutan, metode penyusutan, masa manfaat aset tetap dan akumulasi penyusutan pada awal dan akhir periode.

\section{Penghentian Dan Pelepasan Aset Tetap BPKAPD Muna Barat}

Badan Pengelolaan Keuangan Aset dan Pendapatan Daerah Muna Barat, dalam penghentian dan pelepasan aset tetap berdasarkan peraturan Bupati nomor 59 tahun 2017[29] bahwa ketika dilepaskan atau bila aset secara permanen dihentikan penggunaannya dan dianggap tidak memiliki manfaat ekonomi/sosial signifikan dimasa yang akan datang setelah ada Keputusan dari Kepala Daerah dan/atau dengan persetujuan DPRD. Berdasarkan wawancara dengan bapak Lifan, staf bidang Aset BPKAPD Muna Barat bahwa Aset tetap yang dihentikan dari penggunaan aktif atau operasional kegiatan 
pelayanan Pemerintah Daerah, sudah tidak memenuhi definisi Aset tetap dan harus dipindahkan ke pos Aset Lainnya sesuai dengan nilai tercatatnya.

\section{Pembahasan Penelitian}

\section{Kesesuaian Definisi Aset Tetap Antara PSAP No.07 Tahun 2010 dan Penerapannya pada BPKAPD Muna Barat}

Berdasarkan PSAP Nomor 07[3] Aset tetap aset berwujud adalah yang mempunyai masa manfaat lebih dari 12 (dua belas) bulan untuk digunakan, atau dimaksudkan untuk digunakan, dalam kegiatan pemerintah atau dimanfaatkan oleh masyarakat umum. Sedangkan, Badan Pengelolaan Keuangan Aset dan Pendapatan Daerah Kabupaten Muna Barat mendefinisikan aset tetap berdasarkan Peraturan Bupati nomor 59 tahun 2017[29] tentang kebijakan akuntansi Muna Barat bahwa aset tetap adalah aset berwujud yang mempunyai masa manfaat lebih dari 12 (duabelas) bulan untuk digunakan atau dimaksudkan untuk digunakan, dalam kegiatan pemerintah daerah atau dimanfaatkan oleh masyarakat umum. Termasuk dalam aset tetap pemerintah adalah: (a) Aset tetap yang dimiliki oleh entitas pelaporan namun dimanfaatkan oleh entitas lainnya, misalnya instansi pemerintah lainnya, universitas, dan kontraktor; (b) Hak atas tanah. Jadi dapat dikatakan bahwa pengertian aset tetap dalam Pernyataan Standar Akuntansi Pemerintah Nomor 07 tahun 2010 dan definisi aset tetap pada BPKAPD Muna Barat sesuai.

\section{Kesesuaian Klasifikasi Aset Tetap Antara PSAP No.07 Tahun 2010 dan Penerapannya pada BPKAPD Muna Barat}

Berdasarkan PSAP 07 Tahun 2010[3] bahwa aset tetap diklasifikasikan berdasarkan kesamaan dalam sifat dan fungsinya dalam aktivitas operasi entitas. Berikut klasifikasi aset tetap meliputi tanah, peralatan dan mesin, gedung dan bangunan ,jalan irigasi dan jaringan, aset tetap lainnya, dan konstruksi dalam pengerjaan. Berdasarkan wawancara dengan Bapak Lifan selaku staf bidang BPKAPD Kabupaten Muna Barat, menyatakan bahwa aset tetap yang terdapat di Kabupaten Muna Barat yang terdiri: tanah, gedung dan bangunan, mesin dan peralatan, jalan irigasi dan bangunan, aset tetap lainnya dan konstruksi dalam pengerjaan. Dapat di lihat pada lampiran 2 tentang Neraca Pemerintah Kabupaten Muna Barat Tahun 2018[30]. Jadi dapat dikatakan bahwa pengklasifikasian aset tetap Pernyataan Standar Akuntansi Pemerintah Nomor 07 Tahun 2010 dan pengklasifikasian aset tetap BPKAPD Muna Barat sesuai.

\section{KesesuaianPengakuan Aset tetap Antara PSAP No.07 Tahun 2010 dan Penerapannya pada BPKAPD Muna Barat}

Berdasarkan PSAP 07 Tahun 2010,[3]paragraf 15 menyatakan bahwa aset tetap diakui pada saat manfaat ekonomi masa depan dapat diperoleh dan nilainya dapat diukur dengan handal. Aset tetap untuk dapat diakui sebagai aset tetap harus memenuhi kriteria sebagai berikut, yaitu: (1) Berwujud, (2) Mempunyai masa manfaat lebih dari 12 (dua belas) bulan, (3) Biaya perolehan aset dapat diukur secara andal, (4) Tidak dimaksudkan untuk dijual dalam operasi normal entitas, (5) Dan diperoleh atau dibangun dengan maksud untuk digunakan.

Bapak Lifan, selaku staf bidang Aset BPKAPD Muna Barat juga mengatakan bahwa aset tetap diakui apabila perolehannya sah baik itu dari belanja modal ataupun hibah,dan aset tetap diakui apabila memenuhi kriteria seperti mempunyai masa manfaat lebih dari 12 (dua belas) bulan, biaya perolehan aset dapat diukur secara andal, tidak dimaksudkan untuk dijual dalam operasi normal entitas, diperoleh atau dibangun dengan maksud untuk digunakan dan memenuhi batas minimum kapitalisasi aset tetap yang telah ditentukan oleh pemerintah daerah. Lebih lanjut bapak lifan mengatakan untuk aset tetap yang tidak ditetapkan batas minimum kapitalisasinya, berapapun nilai perolehannya seluruhnya dikapitalisasi sebagai nilainya. Jadi berdasarkan uraian di atas dapat 
disimpulkan bahwa pengakuan aset tetap Pernyataan Standar Akuntansi Pemerintah Nomor 07 Tahun 2010dan Pengakuan Aset tetap BPKAPD Muna Barat sesuai.

\section{KesesuaianPengukuran Aset Tetap Antara PSAP No.07 Tahun 2010 dan} Penerapannya pada BPKAPD Muna Barat

Berdasarkan PSAP 07 Paragraf 20, Aset tetap dinilai dengan biaya perolehan. Apabila penilaian aset tetap dengan menggunakan biaya perolehan tidak memungkinkan maka nilai aset tetap didasarkan pada nilai wajar pada saat perolehan. Kemudian dikatakan bahwa "apabila penilaian aset tetap dengan menggunakan biaya perolehan tidak memungkinkan maka nilai aset tetap didasarkan pada nilai wajar pada saat perolehan". (Komite Standar Akuntansi Pemerintahan 2016: par.21)[14]. Berdasarkan wawancara dengan bapak Lifan,staf bidang aset BPKAPD Muna Barat dalam pengukuran aset tetap pada Pemerintah Kabupaten Muna Barat berdasarkan harga perolehan jika aset tetap tidak dapat diukur dengan harga perolehan maka berdasarkan nilai wajar. Jadi dapat dikatakan bahwa pengukuran aset tetap Pernyataan Standar Akuntansi Pemerintah Nomor 07 Tahun 2010 dan pengukuran aset BPKAPD Muna Barat sesuai.

\section{Kesesuaian Penilaian Awal Aset Tetap Antara PSAP No.07 Tahun 2010 dan Penerapannya pada BPKAPD Muna Barat}

Mengenai Penilaian awal aset tetap, apabila aset tetap diperoleh dari pembelian dalam Pernyataan Standar Akuntansi Pemerintahan No. 07 menyatakan :"Biaya perolehan terdiri dari harga belinya atau konstruksinya, termasuk bea impor dan setiap biaya yang dapat diatribusikan secara langsung dalam membawa aset tersebut ke kondisi yang membuat aset tersebut dapat bekerja untuk penggunaan yang dimaksudkan".Dalam Pernyataan Standar Akuntansi Pemerintahan No. 07 juga disebutkan bahwa "Setiap potongan dagang dan rabat dikurangkan dari harga pembelian" (Komite Standar Akuntansi Pemerintahan 2016: par. 37)[14]. Berdasarkan pernyataan di atas, dalam perolehan awal melalui pembelian, biaya yang dikapitalisasi sebagai harga perolehan adalah harga beli ditambah dengan semua biaya yang dapat diatribusikan langsung agar aset tersebut dapat digunakan sesuai dengan tujuan yang dimaksudkan.Jadi, semua biaya yang dapat diatributkan langsung kepada aset tetap sehingga dapat dimanfaatkan sesuai dengan tujuannya harus dikapitalisasi sebagai harga perolehan. Selain itu, apabila ada pengurangan harga seperti potongan pembelian dan rabat akan dikurangkan dari harga pembelian sebagai pengurang biaya perolehan.

Berdasarkan wawancara dengan bapak Lifan, staf bidang Aset BPKAPD Muna Barat, aset tetap Pemerintah Muna Barat diperoleh dari pembelian dan hibah.Apabila aset tetap dari pembelian maka biaya perolehan suatu aset tetap tersebut terdiri dari harga belinya atau konstruksinya, termasuk dan biaya biaya yang dapat diatribusikan secara langsung dalam membawa aset tersebut ke kondisi yang siap untuk digunakan.Lebih lanjut bapak Lifan mengatakan untuk aset tetap dari hibah dicatat berdasarkan nilai wajar. Jadi dapat dikatakan bahwa penilaian awal aset tetap Pernyataan Standar Akuntansi Pemerintah Nomor 07 Tahun 2010 danpenilaian awal aset tetap BPKAPD Muna Barat sesuai.

\section{Kesesuaian Pengeluaran Setelah Perolehan Antara PSAP No.07 Tahun 2010 dan Penerapannya pada BPKAPD Muna Barat}

Berdasarkan PSAP Nomor 07 paragraf 49-51[3] disebutkan bahwa: "Pengeluaran setelah perolehan awal suatu aset tetap yang memperpanjang masa manfaat atau yang kemungkinan besar memberi manfaat ekonomis di masa yang akan datang dalam bentuk kapasitas, mutu produksi, atau peningkatan standar kinerja, harus ditambahkan pada nilai tercatat aset yang bersangkutan". Kemudian ditetapkan bahwa setiap entitas harus menentukan batasan jumlah biaya tertentu (capitalization thresholds)yang digunakan untuk memisahkan pengeluaran yang dapat dikapitalisasi dan yang tidak dapat dikapitalisasi. 
Badan Pengelolaan Keuangan Aset dan Pendapatan Daerah Kabupaten Muna Barat, dalam pengeluaran setelah perolehan aset tetap berdasarkan Peraturan Bupati nomor 59 tahun 2017[29] bahwa mengenai Pengeluaran-pengeluaran setelah perolehan merupakan belanja modal dan dikapitalisasi menjadi aset apabila (a) Jumlah pengeluaran melebihi batasan minimal jumlah biaya yang dikapitalisasi sebagaimana telah ditetapkan oleh Pemerintah Kabupaten Muna Barat; (b) Pengeluaran-pengeluaran yang memperpanjang umur aset; (c) Pengeluaran-pengeluaran yang meningkatkan kapasitas, manfaat atau mutu produksi; dan (d) pengeluaran-pengeluaran yang akan menambah efisiensi. Jadi dapat kesimpulan bahwa pengeluaran setelah perolehan Pernyataan Standar Akuntansi Pemerintah Nomor 07 Tahun 2010 dan pengeluaran setelah perolehan BPKAPD Muna Barat sesuai.

\section{Kesesuaian Pengukuran Berikutnya Terhadap Pengakuan Awal Antara PSAP No.07 Tahun 2010 dan Penerapannya pada BPKAPD Muna Barat Penyusutan Aset Tetap}

Berdasarkan PSAP 07 Paragraf 53-57[3], paragraf 53, Aset tetap disajikan berdasarkan biaya perolehan aset tetap tersebut dikurangi akumulasi penyusutan. Apabila terjadi kondisi yang memungkinkan penilaian kembali, maka aset tetap akan disajikan dengan penyesuaian pada masing-masing akun aset tetap dan akun di investasikan dalam Aset Tetap. Paragraf 54, Penyesuaian nilai aset tetap dilakukan dengan berbagai metode yang sistematis sesuai dengan masa manfaat. Paragraf 55, masa manfaat aset tetap yang dapat disusutkan harus ditinjau secara periodik dan jika terdapat perbedaan besar dari estimasi sebelumnya, penyusutan periode sekarang dan yang akan datang harus dilakukan penyesuaian.Paragraf 56, Metode penyusutan yang dapat dipergunakan antara lain: (a) Metode garis lurus (straight line method); atau (b) Metode saldo menurun ganda (double declining balance method) (c) Metode unit produksi (unit of production method). Paragraf 57, Selain tanah dan konstruksi dalam pengerjaan, seluruh aset tetap dapat disusutkan sesuai dengan sifat dan karakteristik aset tersebut. Penyusutan aset tetap bukan merupakan metode alokasi biaya untuk periode yang menerima manfaat aset tetap tersebut sebagaimana diberlakukan di sektor komersial. Penyesuaian nilai ini lebih merupakan upaya untuk menunjukkan pengurangan nilai karena pengkonsumsian potensi manfaat aset oleh karena pemakaian dan atau pengurangan nilai karena keusangan dan lain-lain.

Berdasarkan pengamatan peneliti pada Catatan atas Laporan Keuangan yang disusun oleh BPKAPD Muna Barat yaitu laporan rekapitulasi penyusutan aset tetap periode 2018, aset tetap lainnya tidak dilakukan penyusutan padahal dalam PSAP Paragraf 57 menjelaskan bahwa Selain tanah dan konstruksi dalam pengerjaan, seluruh aset tetap dapat disusutkan sesuai dengan sifat dan karakteristik aset tersebut. Hal ini sejalan dengan apa yang diungkapkan oleh bapak Lifan selaku staf bidang Aset BPKAPD Muna Barat bahwa aset tetap lainnya tidak dilakukan penyusutan karena belum ada kebijakan Bupati mengenai penyusutan Aset tetap lainnya dan juga sejak pertama dibuat laporan keuangan pemerintah Kabupaten Muna Barat tahun 2015 memang tidak pernah melakukan penyusutan pada aset tetap lainnya. Lebih lanjut bapak Lifan mengatakan bahwa tidak semua peraturan yang diterapkan pemerintah seperti peraturan pemerintah nomor 71 tahun 2010 ini di terapkan karena disesuaikan dengan keadaan dan kondisi pemerintahan Kabupaten Muna Barat. Berdasarkan uraian tersebut dapat ditarik kesimpulan bahwa PSAP Nomot 07 Tahun 2010 dan penyusutan di BPKAPD Muna Barat belum sepenuhnya sesuai.

\section{Penilaian Kembali Aset Tetap}

Berdasarkan PSAP No.07 menyatakan bahwa :'Penilaian kembali atau revaluasi aset tetap pada umumnya tidak diperkenankan karena Standar Akuntansi Pemerintahan menganut penilaian aset berdasarkan biaya perolehan atau harga pertukaran. Penyimpangan 
dari ketentuan ini mungkin dilakukan berdasarkan ketentuan pemerintah yang berlaku secara nasional".(Komite Standar Akuntansi Pemerintahan 2016: par.59)[14]

Badan Pengelolaan Keuangan Aset dan Pendapatan Daerah Kabupaten Muna Barat, dalam hal penilaian kembali aset tetap berdasarkan Peraturan Bupati Nomor 59 tahun 2017[29] bahwa Penilaian kembali atau revaluasi aset tetap tidak diperkenankan di pemerintah Kabupaten Muna Barat karena kebijakan akuntansi pemerintah daerah menganut penilaian aset berdasarkan biaya perolehan atau harga pertukaran. Hal ini dijelaskan juga Bapak Lifan, selaku staf bidang Aset BPKAPD Muna Barat mengatakan bahwa Pemerintah Muna Barat tidak melakukan penilaian kembali terhadap aset tetap karena nilai aset tetap berdasarkan harga perolehan.Dari uraian diatas, dapat di tarik kesimpulan bahwa penilaian kembali aset tetap Pernyataan Standar Akuntansi Pemerintah Nomor 07 Tahun 2010 dan penilaian kembali pada BPKAPD Muna Barat sesuai.

\section{Kesesuaian Pengungkapan aset tetap Antara PSAP No.07 Tahun 2010 dan Penerapannya pada BPKAPD Muna Barat}

Dalam pengungkapan aset tetap, Komite Standar Akuntansi Pemerintahan (2016: par. 80)[14] menyatakan dalam Pernyataan Standar Akuntansi Pemerintahan menyatakan bahwa laporan keuangan harus mengungkapkan untuk masing-masing jenis aset tetap sebagai berikut: (a) Dasar penilaian yang digunakan untuk menentukan nilai tercatat (carrying amount), (b) Rekonsiliasi jumlah tercatat pada awal dan akhir periode yang menunjukkan yaitu penambahan, pelepasan, akumulasi penyusutan dan perubahan nilai, jika ada dan mutasi aset tetap lainnya, (c) Informasi penyusutan, meliputi:nilai penyusutan, metode penyusutan yang digunakan, masa manfaat atau tarif penyusutan yang digunakan dan nilai tercatat bruto dan akumulasi penyusutan pada awal dan akhir periode.

Berdasarkan pengamatan penulis pada CaLK Kabupaten Muna Barat tahun 2018 bahwa pengungkapan aset tetap yang diungkapkan antara lain nilai tercatat aset tetap, rekonsiliasi jumlah tercatat pada awal sampai akhir periode yang menunjukkan penambahan dan pengurangan aset tetap, kebijakan akuntansi aset tetap mengenai pengakuan sampai pengentian dan pelepasan aset tetap, dan informasi penyusutan yang menunjukkan nilai penyusutan, metode penyusutan, masa manfaat aset tetap dan akumulasi penyusutan pada awal dan akhir periode. Berdasarakan uraian tersebut, dapat di tarik kesimpulan bahwa pengungkapan aset tetap Pernyataan Standar Akuntansi Pemerintah Nomor 07 Tahun 2010 dan pengungkapan aset tetap BPKAPD Muna Barat sesuai.

Kesesuaian Penghentian Dan Pelepasan Aset TetapAntara PSAP No.07 Tahun 2010 dan Penerapannya pada BPKAPD Muna Barat

Berdasarkan PSAP No. 07 disebutkan, "Aset tetap yang secara permanen dihentikan atau dilepas harus dieliminasi dari Neraca dan diungkapkan dalam Catatan atas Laporan Keuangan"(Komite Standar Akuntansi Pemerintahan 2016: par. 78)[14]. Kemudian dikatakan pula bahwa, "Aset tetap yang dihentikan dari penggunaan aktif pemerintah tidak memenuhi definisi aset tetap dan harus dipindahkan ke pos aset lainnya sesuai dengan nilai tercatatnya" (Komite Standar Akuntansi Pemerintahan 2016: par. 79)[14]. Dalam hal penghapusan aset tetap berdasarkan Peraturan Pemerintah Nomor 83/PMK.06/2016[21] yang mengacu pada Peraturan Pemerintah Nomor 71 Tahun 2010 bahwa" penghapusan Barang Milik Negara dilakukan dengan menerbitkan keputusan penghapusan Barang Milik Negara dari pengguna barang setelah mendapat persetujuan dari pengelola barang.

Badan Pengelolaan Keuangan Aset dan Pendapatan Daerah Muna Barat, dalam penghentian dan pelepasan aset tetap berdasarkan peraturan Bupati nomor 59 tahun 2017[29] bahwa ketika dilepaskan atau bila aset secara permanen dihentikan penggunaannya dan dianggap tidak memiliki manfaat ekonomi/sosial signifikan dimasa yang akan datang setelah ada Keputusan dari Kepala Daerah dan/atau dengan persetujuan 
DPRD. Jadi, dapat di tarik kesimpulan bahwa penghentian dan pelepasan aset PSAK Pemerintah Nomor 07 Tahun 2010 dan penghentian dan pelepasan aset tetap BPKAPD una Barat sesuai.

\section{Kesimpulan}

\section{KESIMPULAN DAN SARAN}

Berdasarkan hasil penelitian dan pembahasan yang telah diuraikan sebelumnya tentang evaluasi penerapan akuntansi aset tetap,maka dapat di ambil kesimpulan sebagai berikut:

1. Perlakuan akuntansi aset tetap Pada Badan Pengelolaan Keuangan Aset Dan Pendapatan Daerah (BPKAPD) Kabupaten Muna Barat meliputi klasifikasi, pengakuan, pengukuran, penilaian awal aset tetap, pengukuran berikutnya terhadap pengakuan awal yaitu Penyusutan dan penilaian kembali aset tetap, pengungkapan dan penghentian dan pelepasan aset tetap sesuai dengan PSAP No.07 tahun 2010, kecuali Penyusutan Aset Tetap belum sepenuhnya sesuai.

2. Penyusutan aset tetap belum sepenuhnya sesuai dengan PSAP No.07 tahun 2010 karena tidak melakukan penyusutan terhadap aset tetap lainnya. Berdasarkan wawancara dengan bapak Lifan,staf bidang Aset BPKAPD Muna Barat, aset tetap lainnya tidak disusutkan, belum ada kebijakan Bupati mengenai penyusutan Aset tetap lainnya dan juga sejak pertama dibuat laporan keuangan pemerintah Kabupaten Muna Barat tahun 2015 memang tidak pernah melakukan penyusutan pada aset tetap lainnya. Tidak semua peraturan yang diterapkan pemerintah seperti peraturan pemerintah nomor 71 tahun 2010 di terapkan karena disesuaikan dengan keadaan dan kondisi pemerintahan Kabupaten Muna Barat.

\section{Implikasi}

Berdasarkan hasil analisis dan pembahasan, menunjukkan bahwa Badan Pengelolaan Keuangan Aset Dan Pendapatan Daerah (BPKAPD) Kabupaten Muna Barat dalam perlakuan akuntansi aset tetapnya sudah menerapkan PSAP Nomor 07 tahun 2010 tentang akuntansi aset tetap

\section{Keterbatasan}

Penelitian ini terbatas hanya pada penerapan PSAP No. 07 Tahun 2010 tentang akuntansi aset tetap pada Badan Pengelolaan Keuangan Aset Dan Pendapatan Daerah (BPKAPD) Kabupaten Muna Barat.

\section{Rekomendasi}

Berdasarkan hasil penelitian dan pembahasan yang telah diuraikan sebelumnya tentang evaluasi penerapan akuntansi aset tetap, makapeneliti memberi saran sebagai berikut:

1. Bagi pemerintah, sebaiknya menetapkan kebijakan penyusutan aset tetap berupa penyusutan aset tetap lainnya agar terlihat nilai aktiva yang sebenarnya.

2. Bagi peneliti selanjutnya, penelitian ini diharapkan dapat dijadikan sebagai salah satu referensi untuk penelitian lebih lanjut, terutama bagi peneliti yang melakukan penelitian yang berkaitan dengan aset tetap pemerintah daerah yang lebih sempurna.

\section{DAFTAR PUSTAKA}

[1] B. P. Perundang-undangan and B. Hukum, "Peraturan Pemerintah No. 24 Tahun 2005 Tentang Standar Akuntansi Pemerintahan," Peratur. Pemerintah, pp. 1-17, 2005.

[2] R. Indonesia, "Peraturan Pemerintah No 71 Tahun 2010," pp. 1-413, 2010, doi: 10.1017/CBO9781107415324.004.

[3] S. Akuntansi and P. Pernyataan, "Psap No.07," no. 07, 2010. 
[4] Mursyidi, akuntansi pemerintahan di indonesia PT. Refika Aditama. bandung, 2009.

[5] R. S. Kusuma, "Analisis Kesiapan Pemerintah Dalam Menerapkan Standar Akuntansi Pemerintah Berbasis Akrual (Kasus pada Pemerintah Kabupaten Jember)," Universitas Jember, 2013.

[6] Kieso.dkk, Akuntansi Intermediate, Edisi 12. Jakarta: Penerbit Erlangga, 2008.

[7] "Undang-undang Nomor 17 Tahun 2014 Tentang Keuangan Negara Pasal 32 ayat 2." 2014.

[8] "Peraturan Pemerintah Nomor 24 Tahun 2014." 2014.

[9] Rudianto, Pengantar Akuntansi Konsep \& Tehnik Penyusunan LK. Jakarta: Penerbit Erlangga, 2012.

[10] C.S.Warren.dkk, Pengantar Akuntansi. Jakarta: Penerbit Salemba Empat, 2015.

[11] IAI, "Pernyataan Standar Akuntansi Keuangan No 16." Penerbit Dewan Standar Akuntansi Keuangan IAI, Jakarta, 2015.

[12] P. dan Marisi., Akuntansi Keuangan Aset Tetap dan Aset Tak Berwujud, Edisi 1. Yogyakarta: Graha Ilmu, 2013.

[13] F. Dunia, Pengantar Akuntansi, Edisi 4. Jakarta: Fakultas Ekonomi Universitas Indonesia, 2013.

[14] Komite Standar Akuntansi Pemerintahan, "Standar Akuntansi Pemerintahan Republik Indonesia," Standar Akunt. Pemerintah., pp. 1-269, 2016.

[15] "Peraturan Menteri Dalam Negeri Nomor 64 Tahun 2013 Tentang Standar Akuntansi Pemerintahan Berbasis Akrual Pada Pemerintah Daerah." 2013.

[16] "Buletin Teknis Standar Akuntansi Pemerintahan Nomor 15." Komite Standar Akuntansi Pemerintah, 2014.

[17] KSAP, "Buletin Teknis Nomor 18 Tentang Akuntansi Penyusutan Berbasis Akrual," 2014, doi: 10.1017/CBO9781107415324.004. 